\title{
Induksi PLB Anggrek Vanda sumatrana Schltr. Liar Pada Media MS dengan Penambahan BAP dan NAA serta Ploidisasi dengan Kolkisin
}

\section{PLB Induction of Wild Vanda sumatrana Schltr. on MS Media Suplement with BAP and NAA and Ploidisation by Colchicine Treatment}

\author{
Hanifah Aini $\left.{ }^{1 *}\right)$, Mansyurdin ${ }^{1)}$, dan Suwirmen ${ }^{2)}$ \\ ${ }^{1)}$ Laboratorium Riset Genetika dan Biologi Sel, Jurusan Biologi, Fakultas Matematika dan Ilmu \\ Pengetahuan Alam, Universitas Andalas, Kampus UNAND Limau Manis, Padang, 25163 \\ ${ }^{2)}$ Laboratorium Riset Fisiologi Tumbuhan dan Kultur Jaringan, Jurusan Biologi, Fakultas Matematika dan \\ Ilmu Pengetahuan Alam, Universitas Andalas, Kampus UNAND Limau Manis, Padang, 25163 \\ ${ }^{*}$ Koresponden : hanief.aini@gmail.com
}

\begin{abstract}
The study about PLB induction of wild Vanda sumatrana Schltr. on MS media suplement with BAP and NAA and ploidisation by colchicine treatment was conducted from December 2014 until November 2015 at the Laboratory of Genetics and Cell Biology and Laboratory of Plant Physiology and Tissue Culture, Biology department, Faculty of Mathematic and Natural Science, Andalas University, Padang. The study aimed to 1) knowing the best concentration of 6-Benzyl amino purin (BAP) and $\alpha$-Naphtalene acetic acid (NAA) for Protocorm Like Bodies (PLB) induction from shoot tip of $V$. sumatrana, 2 ) knowing the PLB response of $V$. sumatrana to concentrations and soak period of colchicine and 3) find the effective concentrations and soak period of colchicine to induce tetraploid on PLB of $V$. sumatrana. Shoot tips from in-vitro cultured of $V$. sumatrana were subcultured on Murashinge and Skoog (MS) medium supplement with $3 \mathrm{mg} / \mathrm{l} \mathrm{BAP}+0,5 \mathrm{mg} / \mathrm{l} \mathrm{NAA}, 3 \mathrm{mg} / \mathrm{l} \mathrm{BAP}$ and 1,5 mg/l BAP. PLB of diploid $V$. sumatrana from the best treatment were soaked in $0.05 \%$ and $0.1 \%$ colchicine for 24 and 48 hours respectively in MS liquid medium, as control were set PLB without colchicine treatment. The results showed that MS medium supplemented with $1.5 \mathrm{mg} / \mathrm{l} \mathrm{BAP}$ was the best formula to induce PLB. The highest percentage of survival rate of PLB and percentage of survived PLB regenerated shoot was obtained from $0.05 \%$ colchicine with 24 hours soak period treatment. The effective treatment to induce tetraploid on PLB of $V$. sumatrana Schltr. was obtained from $0.05 \%$ colchicine solution for 24 hours soak period.
\end{abstract}

Keywords: chromosome, colchicine, PLB, polyploidy, Vanda sumatrana

\section{Pendahuluan}

Vanda sumatrana Schltr. merupakan salah satu dari 20 jenis anggrek Vanda yang terdapat di Indonesia (Purwanto dan Endang, 2009) dan termasuk endemik Pulau Sumatera (Comber, 2001). Jenis ini memiliki potensi untuk dijadikan sebagai tanaman hias karena bentuk dan warnanya yang menarik, namun ukuran bunganya relatif kecil jika dibandingkan dengan jenis Vanda budidaya lain yang sudah umum dikomersialkan.
Untuk domestifikasi anggrek ini, perlu dilakukan perbanyakan secara in vitro. Perbanyakan secara in vitro pada anggrek dapat dimulai dengan induksi pembentukan Protocorm Like Bodies (PLB) dengan pemberian zat pengatur tumbuh seperti Auksin, Sitokinin serta kombinasi antara keduanya pada media perlakuan. Zat pengatur tumbuh yang umum digunakan adalah 6-benzyl amino purine (BAP), $\mathrm{N}^{6}$-benzyladenine (BA), Thidiazuron (TDZ), Kinetin $(\mathrm{KN})$ dan Zeatin dari kelompok Sitokinin serta Indole-3-aceticacid (IAA), Indole-3-butyric 
acid (IBA), 2,4-dichlorophenoxyaceticacid (2,4-D) dan $\alpha$-naphthalene acectic acid (NAA) dari kelompok Auksin (Colli dan Kerbauy. 1993; Park et al., 2002; Park, Murthy dan Paek, 2003; Sheelavanthmath et al., 2005). Dari sekian banyak zat pengatur tumbuh yang digunakan, BAP diketahui lebih efektif untuk pembentukan PLB (Colli dan Kerbauy, 1993) serta kombinasinya dengan NAA (Sheelavanthmath et al., 2005), dengan konsentrasi yang berbeda-beda pada setiap tanaman anggrek yaitu berkisar antara 0,0005 mg/l hingga $8,0 \mathrm{mg} / \mathrm{l}$.

Selain perbanyakan secara in vitro, upaya lain yang tak kalah pentingnya adalah dengan meningkatkan ukuran bunga. Menurut Charanasri (1984) cit. Nurmalinda et al. (2011), konsumen lebih menyukai bunga yang berukuran besar untuk kelompok anggrek Vanda. Upaya peningkatan ukuran bunga pada anggrek dapat dilakukan melalui induksi poliploidi (penggandaan kromosom). Atichart dan Bunnag (2007), melaporkan induksi poliploidi pada tanaman anggrek dapat memperbesar ukuran bunganya dibandingkan dengan tanaman diploid. Selanjutnya menurut Singh (2003), pada umumnya tanaman autotetraploid menghasilkan fenotip gigas yaitu lebih besar dari diploidnya. Upaya ini telah dilakukan pada anggrek jenis Cattleya intermedia (Silva et al., 2000), Dendrobium scabrilingue L., (Sarathum et al., 2010), dan Dendrobium strebloceras (Luvina, 2011).

Induksi poliploidi pada sel-sel tanaman lebih banyak menggunakan kolkisin karena mudah larut dalam air (Suryo, 1995). Misalnya pada anggrek $C$. intermedia (Silva et al., 2000), Dendrobium secundum (Atichart dan Bunnag, 2007) dan D. scabrilingue L. (Sarathum et al., 2010). Konsentrasi kolkisin untuk induksi poliploid bervariasi pada setiap tanaman dan setiap organ yang diperlakukan, umumnya berkisar dari $0,02 \%$ sampai $0,1 \%$. Lama waktu perlakuan kolkisin juga bervariasi yaitu dari 3 jam sampai 14 hari tergantung dengan cara perlakuan. Misalnya pada PLB anggrek $\quad C$. intermedia efektif menghasilkan tetraploid dengan konsentrasi 0,05-0,1\% selama 4 hari (Silva et al., 2000), $0,05 \%$ kolkisin selama satu hari pada PLB anggrek D. secundum (B1.) Lindl. (Atichart dan Bunnag, 2007), 0,075\% kolkisin selama 14 hari pada PLB anggrek D. scabrilingue L. (Sarathum et al., 2010), dan 0,02\% kolkisin dengan lama perendaman 6 jam pada akar Dendrobium hybrida (Sulistianingsih, et al., 2004).

Dalam upaya perbanyakan tanaman secara in vitro dan mendapatkan tanaman poliploid dilakukan penelitian ini yang bertujuan untuk; 1) mengetahui konsentrasi BAP dan NAA terbaik untuk pembentukan PLB dari ujung tunas $V$. sumatrana Schltr., 2) mengetahui respon PLB anggrek $V$. sumatrana Schltr. terhadap konsentrasi dan lama perendaman dengan kolkisin dan 3) mengetahui konsentrasi dan lama perendaman PLB dengan kolkisin yang efektif menginduksi tetraploid pada anggrek $V$. sumatrana Schltr.

\section{Metoda Penelitian}

Penelitian ini dilakukan dengan metoda eksperimen yang dimulai dengan induksi pembentukan PLB anggrek $V$. sumatrana secara in vitro, media perlakuan terdiri atas $\mathrm{MS}+3 \mathrm{mg} / \mathrm{l} \mathrm{BAP}+0,5 \mathrm{mg} / \mathrm{l} \mathrm{NAA}, \mathrm{MS}+3$ $\mathrm{mg} / \mathrm{l} \mathrm{BAP}$ dan $\mathrm{MS}+1,5 \mathrm{mg} / \mathrm{l} \mathrm{BAP}$. Induksi poliploidi dilakukan dengan merendam PLB pada media MS + $1 \mathrm{mg} / \mathrm{L}$ BAP tanpa agar (media cair), yang mengandung larutan kolkisin dengan konsentrasi $0,05 \%$ dan $0,1 \%$ yang sudah di sterilkan menggunakan srynge filter berdiameter $0,20 \mu \mathrm{m}$. PLB diinkubasi pada suhu $25^{\circ} \mathrm{C}$ dengan pengocokan $80 \mathrm{rpm}$, lama perendaman 24 jam dan 48 jam untuk masing-masing perlakuan (modifikasi Atichart dan Bunnag, 2007), dan inisiasi tunas PLB pada media MS $+1 \mathrm{mg} / \mathrm{L}$ BAP $+0,5 \mathrm{mg} / \mathrm{L}$ IBA (modifikasi dari Kabir et al., 2013). Sebagai kontrol digunakan PLB anggrek yang tidak diberi perlakuan kolkisin. Sampel yang diinduksi dengan kolkisin berjumlah 25 PLB dengan masingmasing perlakuan ada lima ulangan. Pengamatan sitologi terhadap jumlah kromosom dilakukan dengan pembuatan 
preparat ujung akar menggunakan metoda squash (Singh, 2003).

Parameter pengamatan meliputi persentase pembentukan PLB dan lama waktu pembentukan PLB, tingkat kelulusan hidup (persentase kelulusan hidup PLB dan persentase PLB hidup yang membentuk tunas), tingkat ploidi (jumlah kromosom), ukuran sel (panjang sel, lebar sel dan diameter inti sel) pada ujung akar planlet, serta beberapa ukuran planlet (tinggi planlet, diameter batang, jumlah daun dan jumlah tunas) pada planlet anggrek $V$. sumatrana yang berumur 14 minggu setelah subkultur pada media inisiasi tunas.
Untuk persentase pembentukan PLB, tingkat kelulusan hidup dan tingkat ploidi dianalisa secara deskriptif, sementara ukuran sel dan ukuran planlet dianalisis dengan uji-t pada $\mathrm{p}=5 \%$.

\section{Hasil dan Pembahasan}

\section{Persentase pembentukan PLB}

Persentase terbentuknya PLB tertinggi empat minggu setelah ingkubasi diperoleh dari media MS + 1,5 mg/l BAP dengan persentase PLB yang terbentuk yaitu 87.5 $\%$ (Tabel 1).

Tabel 1. Persentase pembentukan PLB pada Media MS dengan penambahan BAP dan NAA yang berbeda empat minggu setelah ingkubasi

\begin{tabular}{ccc}
\hline Perlakuan & $\begin{array}{c}\text { Jumlah Tunas yang } \\
\text { Diperlakukan }\end{array}$ & $\begin{array}{c}\text { Pembentukan PLB } \\
(\%)\end{array}$ \\
\hline $\mathrm{MS}+3 \mathrm{mg} / \mathrm{l} \mathrm{BAP}+0,5 \mathrm{mg} / \mathrm{l} \mathrm{NAA}$ & 8 & 0 \\
$\mathrm{MS}+3 \mathrm{mg} / \mathrm{l}$ BAP & 8 & 0 \\
$\mathrm{MS}+1,5 \mathrm{mg} / \mathrm{l} \mathrm{BAP}$ & 8 & 87,5 \\
\hline
\end{tabular}

Pemberian BAP dalam konsentrasi rendah efektif menginduksi pembentukan PLB (Gambar 1) dibandingkan dengan pemberian dalam konsentrasi tinggi serta penggabungan dengan NAA. Hal ini disebabkan karena BAP memiliki peranan yang sangat besar dalam pembelahan sel serta bekerja optimum pada konsentrasi yang rendah, sehingga dapat memacu pembelahan sel dengan cepat pada eksplan yang diperlakukan. Colli dan Kerbauy (1993) melaporkan bahwa pemberian
Sitokinin (BAP) mempercepat serta meningkatkan pembentukan PLB pada anggrek Catasetum namun tidak berefek pada pembentukan kalus, perlakuan terbaik diperoleh pada BAP dengan konsentrasi 2 $\mathrm{mg} / \mathrm{l}$ setelah 30 hari ingkubasi dengan pencahayaan yaitu sebesar 4.18 PLB per eksplan dari eksplan ujung akar. Sementara pemberian Auksin exogen (IAA, IBA dan 2,4 D) menurunkan pembentukan PLB pada anggrek tersebut namun meningkatkan pembentukan kalus.

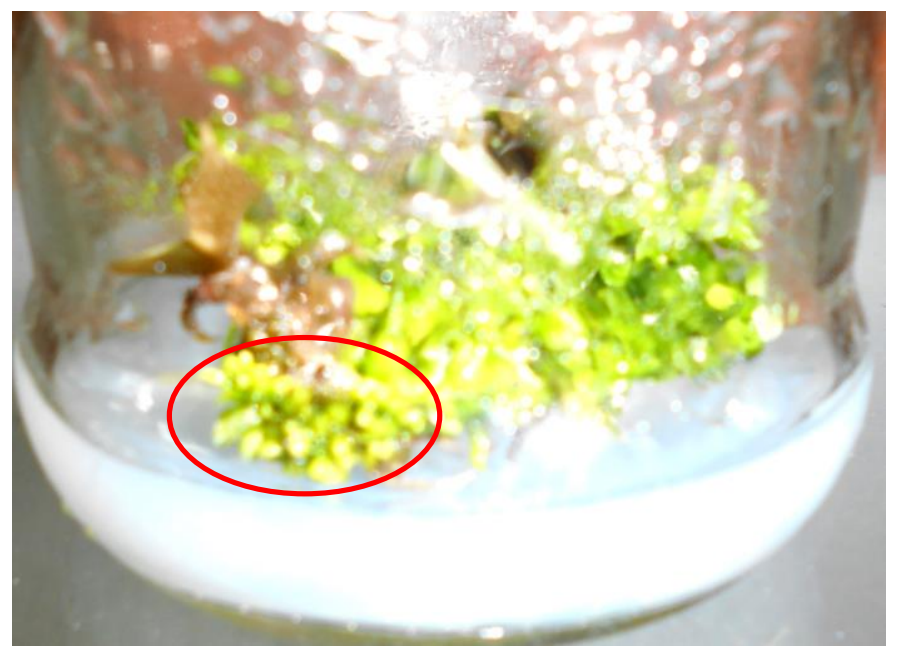

Gambar 1. PLB (bagian yang dilingkari) yang terbentuk pada media MS + 1,5 mg/l BAP 
Sheelavanthmath et al. (2005) melaporkan bahwa konsentrasi $0,001 \mathrm{mg} / \mathrm{l}$ BA efektif menginduksi PLB pada anggrek Aerides crispum dari eksplan protocorm dan daun, PLB yang terbentuk 49.1 PLB per eksplan, dengan waktu pembentukan 5 - 6 minggu. Perlakuan tersebut merupakan perlakuan optimum dibandingakan dengan penggunaan Sitokinin lain seperti TDZ dan Kinetin serta kiombinasinya dengan Auksin. Sementara Park, Murthy dan Paek (2003) melaporkan bahwa medium MS yang ditambahkan dengan $0,0023 \mathrm{mg} / \mathrm{l}$ TDZ menghasilkan persentase pembentukan PLB tertinggi $(47,2 \%)$ dari eksplan ujung akar dengan pembentukan dua hingga enam PLB per eksplan pada anggrek Doritaenopsis.

\section{Tingkat kelulusan hidup}

Persentase kelulusan hidup PLB anggrek $V$. sumatrana tertinggi setelah diperlakukan dengan kolkisin yaitu pada perlakuan $0,05 \%$ kolkisin dengan lama perendaman 24 jam (Tabel 2). Atichart dan Bunnag (2007) melaporkan bahwa persentase kelulusan hidup tertinggi mencapai $78 \%$ pada PLB anggrek $D$. secundum yang diperlakukan dengan $0,05 \%$ kolkisin selama 24 jam.

Tabel 2. Persentase kelulusan hidup PLB dan persentase PLB membentuk tunas pada anggrek Vanda sumatrana Schltr. yang diperlakukan dengan kolkisin 14 minggu setelah subkultur pada media inisiasi tunas

\begin{tabular}{lccc}
\hline \multicolumn{1}{c}{ Perlakuan } & Jumlah PLB & $\begin{array}{c}\text { Kelulusan } \\
\text { Hidup PLB } \\
(\%)\end{array}$ & $\begin{array}{c}\text { PLB yang } \\
\text { Membentuk } \\
\text { Tunas (\%) }\end{array}$ \\
\hline Kontrol & 5 & 100 & 100 \\
0,05\% kolkisin selama 24 jam & 5 & 40 & 100 \\
0,05\% kolkisin selama 48 jam & 5 & 0 & 0 \\
0,1\% kolkisin selama 24 jam & 5 & 20 & 0 \\
0,1\% kolkisin selama 48 jam & 5 & 0 & 0 \\
\hline
\end{tabular}

Semakin tinggi konsentrasi kolkisin dan semakin lama waktu perendaman dengan kolkisin terhadap PLB anggrek $V$. sumatrana menyebabkan persentase kelulusan hidupnya semakin rendah (Tabel 2). Atichart dan Bunnag (2007) melaporkan bahwa pemberian kolkisin pada konsentrasi $0,1 \%$ selama 24 jam menyebabkan kematian PLB anggrek $D$. secundum hingga $25 \%, 35 \%$ pada konsentrasi $0,15 \%$, dan $60 \%$ pada konsentrasi $0,2 \%$. Sun et al. (2009) melaporkan bahwa perlakuan kolkisin $0,4 \%$ menurunkan tingkat kelulusan hidup eksplan daun tanaman pear (Pyrus communis L.) hingga $11 \%$ pada perlakuan selama 24 jam, $19 \%$ pada perlakuan selama 48 jam dan $37 \%$ pada perlakuan selama 72 jam.

Konsentrasi kolkisin $0,1 \%$ berefek sangat toksik terhadap PLB anggrek $V$. sumatrana. Adanya PLB yang mengalami keracunan ditandai dengan perubahan warna PLB menjadi kecoklatan dan akhirnya mati. Hal serupa juga dilaporkan oleh Sarathum et al. (2010) bahwa pemberian kolkisin pada konsentrasi $0,1 \%$ memberikan efek toksik yang sangat nyata pada PLB anggrek D. scabrilingue L., konsentrasi tersebut menimbulkan kematian PLB yang diperlakukan hingga lebih dari $60 \%$. Pemberian kolkisin pada konsentrasi yang tinggi dan waktu perendaman yang lama memberikan efek letal terhadap PLB anggrek Dendrobium scabrilingue dengan ciri terjadinya perubahan warna PLB dari hijau menjadi kuning atau kecoklatan.

Persentase PLB anggrek $V$. sumatrana yang hidup dan membentuk tunas 14 minggu setelah subkultur pada media inisiasi tunas tertinggi diperoleh dari perlakuan kontrol dan $0,05 \%$ kolkisin dengan lama perendama 24 jam yaitu 100\%. Pada perlakuan $0,1 \%$ kolkisin dengan lama perendaman 24 jam, PLB yang hidup tidak mampu beregenerasi membentuk tunas (Tabel 2). Hasil yang didapatkan menunjukkan bahwa semakin tinggi konsentrasi kolkisin dengan lama 
perlakuan yang sama menyebabkan persentase PLB membentuk tunas semakin rendah. Hal ini diduga karena konsentrasi kolkisin yang terlalu tinggi menyebabkan pertumbuhan tanaman terganggu sehingga tanaman tidak mampu beregenerasi dan berkembang ke tahap selanjutnya. Pada PLB anggrek Dendrobium Serdang Beauty yang beregenerasi membentuk tunas, 16 minggu setelah kultur dalam media dengan penambahan kolkisin yaitu, $88 \%$ pada konsentrasi kolkisin $0,0005 \%, 85 \%$ pada $0,001 \%, 80 \%$ pada $0,0015 \%, 40 \%$ pada $0,002 \%$, dan $45 \%$ pada $0,0025 \%$ (Khosravi et al., 2009). Chaicharoen et al. (1995) melaporkan bahwa peningkatan konsentrasi kolkisin dan waktu perendaman semakin lama menyebabkan persentase kalus Morus alba var. S54 yang berkembang membentuk tunas semakin menurun. Konsentrasi 0,025\% kolkisin selama 3 hari kalus yang membentuk tunas sebanyak $44.20 \%$, konsentrasi yang sama selama 5 dan 7 hari turun menjadi $32.70 \%$ dan $32.00 \%$. Demikian juga pada konsentrasi $0,05 \%$ selama 3 hari adalah $42.760 \%$, konsentrasi yang sama selama 5 dan 7 hari turun menjadi $35.40 \%$ dan $32.50 \%$. Menurut Suryo (1995), perlakuan dengan kolkisin pada konsentrasi terlalu tinggi atau waktu perlakuan terlalu lama akan

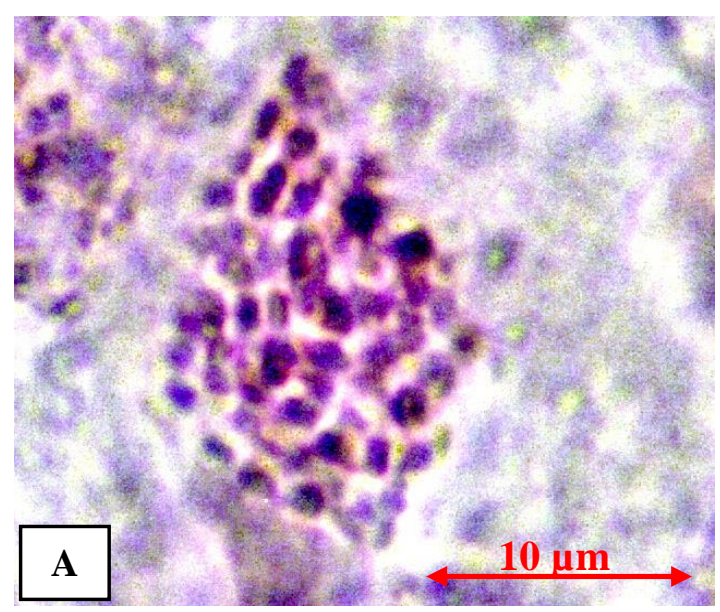

menimbulkan dampak negatif pada tanaman, diantaranya kerusakan sel dan bahkan kematian tanaman.

\section{Tingkat ploidi}

Hasil pengamatan mikroskopis terhadap jumlah kromosom sel ujung akar planlet anggrek $V$. sumatrana pada perlakuan kontrol (Gambar 2. A) menunjukkan bahwa dari lima sel yang diamati jumlah kromosom yang dihitung pada masingmasing sel yaitu 38 dengan demikian dapat dikatakan bahwa jumlah kromosom tanaman diploid (2n) adalah 38. Kamemoto et al. (1964) melaporkan bahwa beberapa spesies dari genus Vanda pada anggrek spesies memiliki jumlah kromosom diploid (2n) sebanyak 38, diantaranya Vanda. corulea Griff., $V$. corulescens Griff., $V$. denisoniana Bens. \& Rchb. f. (green to yellow), V. lautica Guill., V. teres Ldl., V. (Vanda) parishii (Veitch \& Rchb. f.) Schltr.. Spesies lain dari genus Vanda yang dilaporkan oleh Utami dan Hartati (2012), yaitu $V$. tricolor juga memiliki jumlah kromosom $2 \mathrm{n}=38$. Sedangkan pada $V$. denisoniana Bens. \& Rchb. f. (brown) 10 tanaman jumlah kromosomnya $2 \mathrm{n}=76$ dan empat tanaman $2 \mathrm{n}=38$ (Kamemoto et al., 1964).

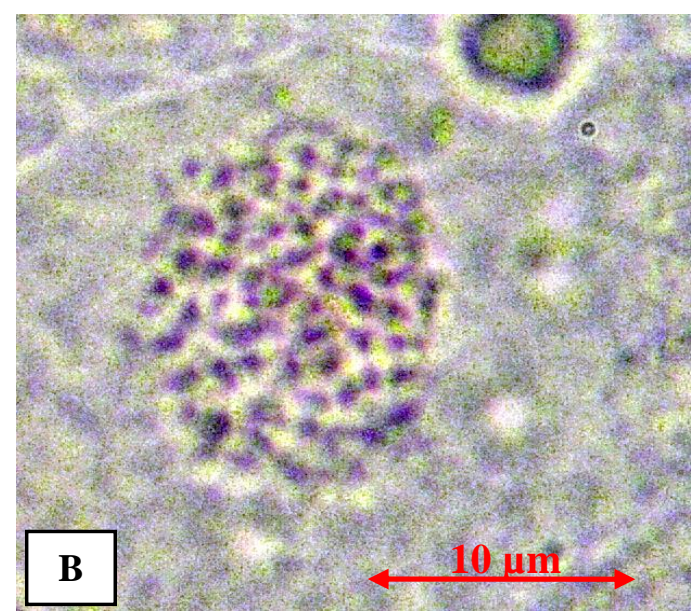

Gambar 2. Kromosom pada sel ujung akar planlet anggrek V. sumatrana Schltr.; A) Kontrol, B) Hasil perlakuan $0,05 \%$ kolkisin selama 24 jam.

Perlakuan $0,05 \%$ kolkisin selama 24 jam mampu menghasilkan tanaman anggrek V. sumatrana tetraploid (Gambar 2. B). Jika dibandingkan dengan perlakuan lain maka perlakuan tersebut merupakan perlakuan yang efektif menginduksi tetraploid pada PLB anggrek $V$. sumatrana secara in vitro. Atichart dan Bunnag (2007) melaporkan bahwa $0,05 \%$ kolkisin dengan perendaman selama 24 jam merupakan perlakuan terbaik 
untuk menghasilkan tanaman tetraploid pada anggrek $D$. secundum. Silva et al. (2000) juga melaporkan bahwa konsentrasi $0,05 \%$ dan $0,1 \%$ kolkisin selama 4 hari merupakan perlakuan yang efektif menginduksi poliploid pada anggrek $C$. intermedia. Sarathum et al. (2010) melaporkan bahwa kolkisin 0,075\% dengan perlakuan 14 hari merupakan perlakuan terbaik untuk menghasilkan tanaman tetraploid pada anggrek Dendrobium scabrilingue.

\section{Ukuran sel dan ukuran planlet}

Ukuran panjang sel, lebar sel dan diameter inti sel yang diamati pada sel ujung akar tanaman hasil perlakuan $0,05 \%$ kolkisin selama 24 jam meningkat dibandingkan dengan tanaman kontrol dan berbeda nyata berdasarkan uji-t taraf kepercayaan 5\% (Tabel 3). Hasil tersebut merupakan indikasi terjadinya peningkatan ploidi pada tanaman. Hal serupa juga dilaporkan oleh Daryono (1998), pada tanaman melon kultivar Sky Rocket yang diberi perlakuan kolkisin dapat memperbesar luas permukaan sel ujung akar hingga 1,7 sampai 3,4 kali ukuran sel kontrol, yang diperoleh pada konsentrasi $0,1 \% ; 0,5 \%$ dan $1 \%$ dengan lama perendaman 6 jam, pada konsentrasi $0,05 \% ; 0,1 \% ; 0,5 \%$ dan $1 \%$ dengan lama perendaman 12 jam. Setyowati et al. (2013) melaporkan bahwa konsentrasi $0,0001 \%$ kolkisin selama tiga hari nyata meningkatkan panjang, lebar dan diameter inti sel ujung akar bawang wakegi kultivar lembah palu dibandingkan dengan tanaman kontrol.

Tabel 3. Ukuran sel ujung akar planlet anggrek Vanda sumatrana Schltr. kontrol dan hasil perlakuan $0,05 \%$ kolkisin selama 24 jam

\begin{tabular}{ccc}
\hline Ukuran & Kontrol & $0,05 \%$ kolkisin selama 24 jam \\
\hline Panjang Sel $(\mu \mathrm{m}) \pm \mathrm{sd}$ & $20,5 \pm 5.7^{\mathrm{b}}$ & $35.8 \pm 6.8^{\mathrm{a}}$ \\
Lebar Sel $(\mu \mathrm{m}) \pm \mathrm{sd}$ & $15.1 \pm 4.8^{\mathrm{b}}$ & $26.1 \pm 4.3^{\mathrm{a}}$ \\
Diameter Inti Sel $(\mu \mathrm{m}) \pm \mathrm{sd}$ & $9.3 \pm 3.8^{\mathrm{b}}$ & $16.0 \pm 4.9^{\mathrm{a}}$ \\
\hline
\end{tabular}

Keterangan: Angka pada baris yang diikuti oleh huruf yang sama tidak berbeda nyata berdasarkan uji-t pada $\mathrm{p}=5 \%$

Planlet $V$. sumatrana hasil perlakuan kolkisin $0,05 \%$ selama 24 jam memiliki jumlah daun lebih banyak dibandingkan tanaman kontrol dan berbeda nyata berdasarkan uji-t pada taraf kepercayaan
5\% (Tabel 4). Meningkatnya jumlah daun pada perlakuan tersebut merupakan indikasi morfologi terjadinya peningkatan ploidi pada tanaman dan memperkuat hasil pengamatan sitologi.

Tabel 4. Ukuran planlet anggrek Vanda sumatrana Schltr. kontrol dan hasil perlakuan 0,05\% kolkisin selama 24 jam 14 minggu setelah subkultur pada media inisiasi tunas

\begin{tabular}{ccc}
\hline Ukuran & Kontrol & $0,05 \%$ kolkisin selama 24 jam \\
\hline Tinggi Planlet $(\mathrm{cm}) \pm \mathrm{sd}$ & $0.87 \pm 0,11^{\mathrm{a}}$ & $1.12 \pm 0,16^{\mathrm{a}}$ \\
Diameter Batang $(\mathrm{cm}) \pm \mathrm{sd}$ & $0,21 \pm 0,03^{\mathrm{a}}$ & $0,18 \pm 0,04^{\mathrm{a}}$ \\
Jumlah Daun $\pm \mathrm{sd}$ & $2.2 \pm 0,45^{\mathrm{b}}$ & $5.0 \pm 0^{\mathrm{a}}$ \\
Jumlah Tunas $\pm \mathrm{sd}$ & $1.4 \pm 0,55^{\mathrm{a}}$ & $4.5 \pm 3.54^{\mathrm{a}}$ \\
\hline
\end{tabular}

Keterangan: Angka pada baris yang diikuti oleh huruf yang sama tidak berbeda nyata berdasarkan uji-t pada $\mathrm{p}=5 \%$

Ukuran tinggi tanaman, diameter batang dan jumlah tunas antara tanaman kontrol dengan hasil perlakuan $0,05 \%$ kolkisin dengan lama perendaman 24 jam tidak berbeda nyata berdasarkan uji-t pada taraf kepercayaan 5\%. Hasil yang didapatkan ini menunjukkan bahwa peningkatan jumlah kromosom pada tanaman hasil perlakuan dengan kolkisin belum mampu meningkatkan ukuran tinggi tanaman, diameter batang, serta jumlah tunas tanaman anggrek $V$. sumatrana secara nyata dibandingkan dengan tanaman kontrol. Hal ini diduga karena waktu pengamatan yang relatif pendek, selain itu juga diduga karena peningkatan jumlah kromosom didalam inti sel memperlama fase interfase sehingga proses pembelahan 
sel juga berlangsung lambat. Sulistianingsih et al. (2004) melaporkan bahwa tanaman anggrek Dendrobium Hibrida yang diperlakukan dengan kolkisin memperlihatkan pengaruh nyata pada peningkatan diameter batang, ukuran bunga, ketebalan sepal, ketebalan labellum dan jumlah kromosom kecuali ketebalan petal. Pada anggrek Dendrobium scablrilingue yang dilaporkan oleh Sarathum et al. (2010) diketahui bahwa tanaman tetraploid hasil perlakuan kolkisin memperlihatkan ukuran planlet menjadi lebih lebar, 2-3 kali lebih tebal, diameter batang serta akar lebih meningkat dibanding tanaman kontrol setelah kultivasi selama delapan bulan.

\section{Kesimpulan}

Berdasarkan hasil penelitian induksi Protocorm Like Bodies (PLB) dan ploidisasi pada anggrek Vanda sumatrana Schltr. liar dengan kolkisin secara in vitro didapatkan kesimpulan sebagai berikut :

1. Perlakuan terbaik untuk menginduksi pembentukan PLB pada anggrek Vanda sumatrana Schltr. adalah media MS + $1,5 \mathrm{mg} / \mathrm{l}$ BAP dengan PLB yang terbentuk $87.5 \%$, empat minggu setelah subkultur.

2. Persentase kelulusan hidup PLB dan persentase PLB hidup yang membentuk tunas tertinggi diperoleh dari perlakuan $0,05 \%$ kolisin selama 24 jam. Untuk perlakuan kolkisin dengan konsentrasi $0,05 \%$ selama 48 jam dan $0,1 \%$ selama 48 jam semua PLB yang diperlakukan mengalami kematian.

3. Konsentrasi kolkisin $0,05 \%$ dengan perendaman PLB selama 24 jam efektif untuk menginduksi PLB anggrek $V$. sumatrana menjadi tanaman tetraploid.

\section{Ucapan Terimakasih}

Terimakasih penulis ucapkan kepada Team Manajemen Dikti yang telah memberi dana awal dalam penelitian ini melalui Program Kreativitas Mahasiswa Penelitian (PKM-P), kepada kepala Lab. Riset Genetika dan Biologi Sel serta Kepala Lab. Riset Fisiologi Tumbuhan dan Kultur Jaringan
Jurusan Biologi Universitas Andalas atas fasilitas yang diberikan selama penelitian. Kepada Dr. Tesri Maideliza, Prof. Dr. Syamsuardi, Dr. Dewi Imelda Roesma, Dr. Tjong Hon Tjong, M. Idris, M.Si atas bantuan dan saran-saran selama penelitian ini berlangsung.

\section{Daftar Pustaka}

Atichart, P dan S. Bunnag. 2007. Polyploid induction in Dendrobium secundum (B1.)Lindl. by in vitro techniques. Thai Journal of Agricultural Science., 40(1-2): 91-95.

Chaicharoen, S., A. Satrabhandhu dan M. Khuatrachue. 1995. In vitro induction of poliploidy in white mulberry (Morus alba var. s54) by colchicine treatment. J. Sci. Soc. Thailand. 21: 229-242.

Chulalaksananukul, W dan W. Chimnoi. 1999. Polyploid Induction in Centella asiatica (L.) Urban by Colchicine Treatment. J. Sci. Res. Chula. Univ. 24 (2): 55-65.

Colli, S dan G. B. Kerbauy. 1993. Direct root tip conversion of Catasetum into protocorm-like bodies. Effects of auxin and cytokinin. Plant Cell, Tissue and Organ Culture. 33: 39-44.

Comber, J. B. 2001. Orchids of Sumatra. The Royal Botanic Gardens. Kew.

Daryono, B. S. 1998. Pengaruh kolkisin terhadap pembentukan sel-sel melon tetraploid. Buletin Agro Industri, (5): $2-11$.

Kabir, M. F., M. S. Rahman., A. Jamal., M. Rahman dan M. Khalekuzzaman. 2013. Multiple shoot regeneration in Dendrobium fimbriatum Hook An ornamental orchid. The Journal of Animal \& Plant Sciences, 23(4): 1140-1145

Kamemoto, H., R. Sagarik dan S. Kasemsap. 1964. Chromosome numbers of sarcanthine orchid spesies 
of Thailand. Nat. Hist. Bull. Siam Soc. 20: 235-241.

Khosravi, A. R., M. A. Kadir., S. B. Kadzemin., F. Q. Zaman dan A. E. De Silva. 2009. RAPD analysis of colchicine induced variation of the Dendrobium Serdang beauty. African Journal of Biotechnology, 8(8): 14551465.

Luvina W.S, R. 2011. Induksi poliploidi pada anggrek Dendrobium strebloceras dengan kolkhisin. Universitas Brawijaya. Malang (Abstr).

Nurmalinda., S. Kartikaningrum., N. Q. Hayati dan D. Widyastoety. 2011. Preferensi konsumen terhadap anggrek Phlaenopsis, Vanda dan Dendrobium. J. Hort. 21(4): 372-384

Park, S. Y., E. C. Yeung., D. Chakrabarty dan K. Y. Paek. 2002. An efficient direct induction of protocorm-like bodies from leaf subepidermal cells of Doritaenopsis hybrid using thinsection culture. Plant Cell Rep. 21: 46-51.

Park, S. Y., H. N. Murthy dan K. Y. Paek. 2003. Protocorm-like body induction and subsequent plant regeneration from root tip cultures of Doritaenopsis. Plant Science. 164: 919-923.

Purwanto, A. W dan S. Endang. 2009. Pesona kecantikan anggrek vanda. Kasinus. Yogyakarta

Sarathum, S., M. Hegele., S. Tantiviwat dan M. Nanakorn. 2010. Effect of concentration and duration of colchicine treatment on polyploiy induction in Dendrobium scabrilingue L. Europ.J.Hort.Sci. 75 (3): 123-127.

Setyowati, M., E. Sulistyaningsih dan A. Purwanto. 2013. Induksi poliploidi pada kultur meristem batang bawang wakegi (Allium x wakegi Araki). Ilmu Petanian. 16(1); 58-76.

Sheelavanthmath, S. S., H. N. Murthy., B. P. Hema., E. J. Hahn dan K. Y. Paek. 2005. High frequency of protocorm like bodies (PLBs) induction and plant regeneration from protocorm and leaf sections of Aerides crispum. Scientia Horticulturae. 106: 395-401.

Silva, P. A. K. X. d. M. e., S. C. Jacques dan M. H. B. Zanettini. 2000. Induction and identification of polyploids in Cattleya intermedia LINDL. (Orchidaceae) by in vitro techniques. Ciencia Rural, Santa Maria, 30(1): 105-111.

Singh, R. J. 2003. Plant cytogenetics. Second Edition. CRC PRESS, Boca Raton, London, New York, Washington, D.C.

Sulistianingsih, R., Z.A. Suyanto dan E. N. Anggia. 2004. Peningkatan kualitas anggrek Dendrobium hibrida dengan pemberian kolkisin. Ilmu Pertanian, 11(1): 13-21.

Sun, Q., H. Sun., L. Li dan R. L. Bell. 2009. In vitro colchicine-induced polyploid plantlet production and regeneration from leaf explants of the diploid pear (Pyrus communis L.) cultivar, 'Fertility'. Journal of Horticultural Science \& Biotechnology, 84(5): 548-552.

Suryo. 1995. Sitogenetika. Gadjah Mada University Press. Yogyakarta.

Utami, D. S dan S. Hartati. 2012. Perbaikan genetik anggrek melalui persilangan intergenerik dan perbanyakan secara in vitro dalam mendukung perkembangan anggrek di Indonesia. Agrineca. 12(2). 